\title{
Assessment of water quality status of Doyang River, Nagaland, India, using Water Quality Index
}

\author{
Akumtoshi $\mathrm{Lkr}^{1} \cdot$ M. R. Singh ${ }^{1} \cdot$ Neizo Puro $^{1}$ \\ Received: 25 June 2018 / Accepted: 23 December 2019 / Published online: 3 January 2020 \\ (c) The Author(s) 2020
}

\begin{abstract}
The Doyang River of Wokha district, Nagaland, NE India, has a strong economic and traditional attachment to the local people. It provides sufficient fertile plains and slopes for cultivation, good grounds for community fishing and hunting. It is not only important for the people of Wokha but also for the state of Nagaland because of the rich natural resources it provides. This study was conducted to assess the Water Quality Index (WQI) of the Doyang River from eight selected sampling stations. Maximum WQI values were recorded during monsoon season in all the stations followed by pre-monsoon and post-monsoon. Sampling stations located in the upstream of the river experience deteriorating WQI due to the presence of hydroelectric dam, changing landuse practices, increasing settlements and deforestation in the catchment and river banks. The overall WQI values showed good water quality status indicating suitability for different human uses. The present study points out that $\mathrm{pH}, \mathrm{DO}$ and BOD played a central role in affecting the WQI of the river; however, in case of nutrient elements no such significant roles were observed in affecting the water quality of the river. The condition of water quality in our present study felt the necessity to adopt proper management policy and conservation efforts along the riparian zones of Doyang River.
\end{abstract}

Keywords Doyang River · Water Quality Index (WQI) · Permissible limit · Seasonal values · Riparian forest

\section{Introduction}

Rivers are an important source of freshwater but are also vulnerable to kinds of pollution to both point and nonpoint sources. Anthropogenic activities related to extensive urbanization, agricultural practices, industrialization and population expansion have led to water quality deterioration in many parts of the world. The adjacent landscapes that act as an interface between the aquatic and terrestrial ecosystem called the 'riparian zones play a significant role in controlling water and chemical exchange between surrounding land and stream systems (Burt and Pinay 2005). Disturbances in this landscape can lead to deterioration of water quality as they influence the flows of energy and material between the terrestrial and aquatic (Fausch et al. 2010) interface. Riparian zones form a unique ecosystem and act as 'buffer zones' between upland and streams (Hill 1996; Lowrance 1998) and are vital to the health of the watershed. The riparian forest

\section{R. Singh}

romeomaibam@gmail.com

1 Department of Botany, Nagaland University, Lumami 798627, India along the river that receives and processes water, sediments and nutrients transports from upslope areas and effectively functions as sinks for sediment and nutrients, thus regulating the nutrient loading to the aquatic system (Luke et al. 2007; Mayer et al. 2007). Water quality of any specific area or source may be assessed using physical, chemical and biological parameters; it is considered harmful and unfit for different human usage and other agricultural activities once they occur more than the well-defined limits (ICMR 1975; BIS 2003). Accordingly, the suitability of water for its usage may be categorized or described in terms of Water Quality Index (WQI), which is one of the most effective ways to describe the status of water quality. It is calculated from the point of aptness of surface water for human consumption (Atulegwu and Njoku 2004).

WQI is a single number that expresses water quality by aggregating the measurements of water quality parameters (such as dissolved oxygen, $\mathrm{pH}$, nitrate and total hardness). It reduces the bulk of information from the several water quality parameters into a single value and expresses the data in a simplified and logical form (Semiromi et al. 2011). Assessment of water quality could provide us the overall information on the quality of the water bodies and its potential 
threat to various uses. The application of WQI is a useful method in assessing the water quality of the river. It helps to understand the overall water quality status of individual sampling stations at a certain time (Yogendra and Puttaiah2008) and its suitability for various beneficial uses. The concept of indices to represent gradation in water quality was first proposed by Horton (1965), since then numerous water quality indices have been formulated that can easily evaluate the overall water quality of an area promptly and efficiently. The general WQI developed by Brown et al. (1970) has undergone much improved modification suitable for a different purpose. Many workers like Debels et al. (2005), Yisa and Jimoh (2010), Akoteyon et al. (2011), Othman et al. (2012), Naubi et al. (2016), Ewaid (2017) and Bouslah et al. (2017) have worked out the study of WQI of different rivers. Similarly, in India, Yogendra and Puttaiah (2008), Kumar et al. (2011), Sharma and Kansal (2011), Singh and Kamal (2014) and Shah and Joshi (2017) have also worked on WQI of rivers in different states of India. So far only a few studies on WQI from the northeastern part of India, mainly confined to Assam and Manipur (Singh et al. 2016, Bora and Goswami 2017), have been reported.

Nagaland state is dissected by a number of seasonal and perennial rivers and rivulets. Major rivers that flow westward into Brahmaputra River of Assam are Dhansiri, Doyang and Dikhu. The Doyang River passes through a great part of Wokha district of Nagaland and is called 'POFU' by the local inhabitants (Lothas) which simply means 'encircle' because the river flows right through the middle of the district touching all the three ranges encircling the whole district. The Dam area of Doyang River is an important ecotourism spot for bird-watchers as it is a roosting place of a migratory bird Amur falcon (Falco amurensis). The falcons travel almost 22,000 km every year (October-November) from southeastern Siberia and Northern China in millions and spend nearly a month around the vicinity of the Dam. The river also has a strong economic and traditional attachment to the local people because of its sufficient fertile plains and slopes for cultivation. However, the changing landuse practices, increasing population and deforestation in the catchment and river banks, shifting cultivation along the river have threatened the riparian habitats as never before. This has drawn much attention in preserving the riparian vegetation along the streams and in other sensitive areas in order to protect the water quality and habitat value of these areas. Geomorphology and seasonal variation of physicochemical parameters of Doyang River had been worked out by Imnatoshi and Ahmed (2012); however, there has been no scientific investigation on water quality assessment of Doyang River till date. In the present study, the application of WQI would give us comparative results of the water quality status of Doyang River at different sampling stations in varying seasons. The main reason for using WQI in the present study is to test the hypothesis whether the riparian forest present along the stretch of Doyang River may help in improving the status of water quality besides several pockets of landuse practices being found. This study would provide us a comprehensive water quality status of the Doyang River. It would ultimately pave ways for future management and action plans so as to protect the riparian zones that face pressure from different landuse practices, and facilitate improvement of the water quality.

\section{The study area}

Nagaland has a total geographical area of $16,579 \mathrm{~km}^{2}$ extending from $25^{\circ} 6^{\prime} \mathrm{N}$ to $27^{\circ} 4^{\prime} \mathrm{N}$ Latitude and $93^{\circ} 20^{\prime}$ E-95 $15^{\prime}$ E Longitude. The state is bounded by Assam in the north and west, by Myanmar and Arunachal Pradesh in the east and by Manipur in the south. Nagaland experiences heavy rainfall, and the annual rainfall varies from 100 to $300 \mathrm{~cm}$. The monsoon seasons last for a period of 5 months from May to September with June, July and August experiencing the highest rainfall. The Doyang River is one of the major rivers in Nagaland and runs along the southern boundary of the state. It originates from the Japfü Hill near the southern slope of Mao in Manipur and moves in a southwest direction passing through Kohima district and flows northward into Zunheboto and Wokha. The river has a length of $167 \mathrm{~km}$ (from Gariphema/Ghathashi area to Liphi) and a catchment area of $3283 \mathrm{~km}^{2}$ (Laishram and Yumnam 2016). It passes through a great part of Wokha district of Nagaland and flows south westerly into Dhansiri in Sibsagar District of Assam and finally joins the mighty Brahmaputra River of Assam. The main tributaries of Doyang are Tsui, Tullo and Tishi. The present study was conducted within a stretch of 40-45 km of Doyang River under Wokha district, Nagaland. The Doyang hydroelectric project (DHEP) is located in this river at $26^{\circ} 14 \mathrm{~N}$ Latitude and $94^{\circ} 16 \mathrm{E}$ Longitude of Wokha district. The large reservoir lake created for generating hydroelectric power is more than $20 \mathrm{~km}^{2}$, and it also comes under the present study area. There are several landuse practices around the catchment area of the Doyang hydroelectric dam and along the riparian zone of the river. Figure 1 shows the landuse/landcover (LULC) map of the present study area. The characteristics features of the selected sampling stations, their coordinates and elevation along the Doyang River are presented in Table 1.

\section{Materials and methods}

Along the stretch of Doyang River, surface water samples were collected from the eight sampling stations. Sampling was done during the first week of each month from June 2016 


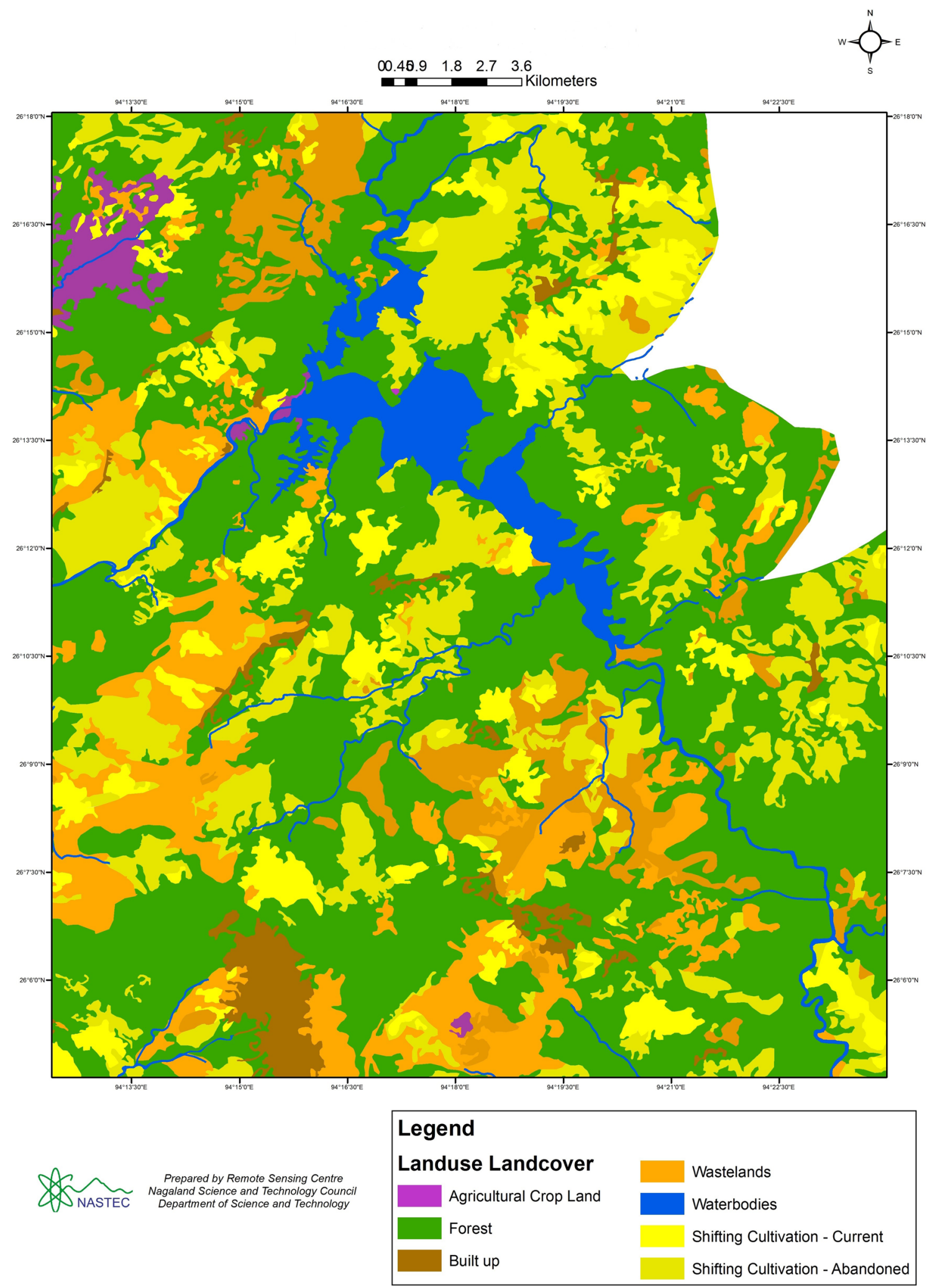

Fig. 1 Map showing the landuse/landcover (LULC) of the study area

to May 2017 for a period of 1 year. The months were later categorized into three different seasons, namely pre-monsoon
(PRM), monsoon (MON) and post-monsoon (POM) for interpretation of data. Figure 2 shows the sampling location 
Table 1 Characteristic features of the sampling station, their coordinates and elevation along Doyang River

\begin{tabular}{|c|c|c|c|c|c|}
\hline Sl. no & Sampling station & Station code & Characteristics of sampling station & Coordinates & Elevation (msl) \\
\hline 1. & Station 1 & S 1 & $\begin{array}{l}\text { Upstream forested area inhabited by some residential families and } \\
\text { ongoing construction site of highway bridge (NH 2). }\end{array}$ & $\begin{array}{l}26^{\circ} 07.298^{\prime} \mathrm{N} \\
094^{\circ} 23.099^{\prime} \mathrm{E}\end{array}$ & $348 \mathrm{~m}$ \\
\hline 2. & Station 2 & S 2 & $\begin{array}{l}\text { Midstream forested area located around the vicinity of hydroelectric } \\
\text { dam along the river. }\end{array}$ & $\begin{array}{l}26^{\circ} 13.331^{\prime} \mathrm{N} \\
094^{\circ} 18.747^{\prime} \mathrm{E}\end{array}$ & $314 \mathrm{~m}$ \\
\hline 3. & Station 3 & S 3 & $\begin{array}{l}\text { Jhum cultivate site located around the vicinity of hydroelectric dam } \\
\text { along the river }\end{array}$ & $\begin{array}{l}26^{\circ} 14.542^{\prime} \mathrm{N} \\
094^{\circ} 17.529^{\prime} \mathrm{E}\end{array}$ & $335 \mathrm{~m}$ \\
\hline 4. & Station 4 & S 4 & $\begin{array}{l}\text { Teak plantation site located around the vicinity of hydroelectric dam } \\
\text { along the river }\end{array}$ & $\begin{array}{l}26^{\circ} 14.214^{\prime} \mathrm{N} \\
094^{\circ} 16.933^{\prime} \mathrm{E}\end{array}$ & $332 \mathrm{~m}$ \\
\hline 5. & Station 5 & S 5 & Point of dam construction site inhabited by some residential families. & $\begin{array}{l}26^{\circ} 13.811^{\prime} \mathrm{N} \\
094^{\circ} 15.779^{\prime} \mathrm{E}\end{array}$ & $325 \mathrm{~m}$ \\
\hline 6. & Station 6 & S 6 & Residential site along the downstream of the river & $\begin{array}{l}26^{\circ} 13.752^{\prime} \mathrm{N} \\
094^{\circ} 15.068^{\prime} \mathrm{E}\end{array}$ & $266 \mathrm{~m}$ \\
\hline 7. & Station 7 & S 7 & Abandoned Jhum site along the downstream of the river & $\begin{array}{l}26^{\circ} 13.078^{\prime} \mathrm{N} \\
094^{\circ} 14.661^{\prime} \mathrm{E}\end{array}$ & $257 \mathrm{~m}$ \\
\hline 8. & Station 8 & S 8 & $\begin{array}{l}\text { Downstream forested area with different landuse like Jhumming and } \\
\text { teak plantation (monoculture) }\end{array}$ & $\begin{array}{l}26^{\circ} 12.622^{\prime} \mathrm{N} \\
094^{\circ} 14.211^{\prime} \mathrm{E}\end{array}$ & $243 \mathrm{~m}$ \\
\hline
\end{tabular}

selected along the river for the study of WQI. Water samples were collected from the first $20 \mathrm{~cm}$ of the water column using a bottom-weighted polyethylene flask, previously washed in the laboratory with lapoline, $10 \% \mathrm{HCl}$ and then with a water sample from each spot. In this study, twelve physicochemical parameters of water were selected, namely $\mathrm{pH}$, electrical conductivity (EC), total dissolved solids (TDS), total alkalinity (TA), total hardness (TH), calcium $\left(\mathrm{Ca}^{2+}\right)$, magnesium $\left(\mathrm{Mg}^{2+}\right)$, chloride $\left(\mathrm{Cl}^{-}\right)$, nitrate $\left(\mathrm{NO}_{3}^{-}\right)$, sulfate $\left(\mathrm{SO}_{4}{ }^{2-}\right)$, dissolved oxygen (DO) and biological oxygen demand (BOD) for generating the overall WQI of Doyang River. Parameters like $\mathrm{pH}$ and TDS were measured on the spot with the help of pen-type digital $\mathrm{pH}$ and TDS meter. Conductivity was analyzed with the help of a digital conductivity meter in the laboratory. Total alkalinity, total hardness, calcium, magnesium and chloride were analyzed by the titration method. For the measure of dissolved oxygen, fixatives were added on the spot and analyzed thereafter using Winkler's method. Separate samples for BOD were also collected, incubated in the dark at $20{ }^{\circ} \mathrm{C}$ for 5 days and analyzed thereafter. Parameters like nitrate and sulfate were analyzed using the double-beam UV-visible spectrophotometer. All the parameters were analyzed using standard methods as prescribed by Trivedy and Goel (1986) and APHA (2005). Finally, the WQI was calculated by employing the Weighted Arithmetic Index method developed by Brown et al. (1970) which is given in the following equation:

$\mathrm{WQI}=\sum Q_{i} W_{i} / \sum W_{i}$

The quality rating scale $\left(Q_{i}\right)$ for each parameter was calculated by using the expression:
$Q_{i}=100\left[\left(V_{i}-V_{o} / S_{i}-V_{o}\right)\right]$

where $V_{i}=$ concentration of $i$ th parameter in the water sample analyzed.

$V_{o}=$ ideal value of parameter in pure water, i.e., $V_{o}=0$ (except $\mathrm{pH} 7.0$ and $\mathrm{DO}=14.6 \mathrm{mg} / \mathrm{l}), S_{i}=$ recommended standard value of ith parameter.

The unit weight $\left(W_{i}\right)$ for each water quality parameter is calculated by using the following formula:

$W_{i}=K / S_{i}$

where $\mathrm{K}=$ proportionality constant calculated by using the equation

$K=\frac{1}{\sum\left(1 / S_{i}\right)}$

The WQI range, its status and possible usage (Brown et al. 1972) are presented in Table 2.

\section{Results and discussion}

\section{Water quality parameters}

The values of water quality parameters obtained from all the sampling stations in three different seasons are presented in Table 3. The $\mathrm{pH}$ is a measure of the acidic or alkaline condition of water and serves as an important indicator of water quality and determines the suitability of water for various purposes. The experimental water bodies recorded approximately neutral or slightly alkaline in nature (Bouslah 


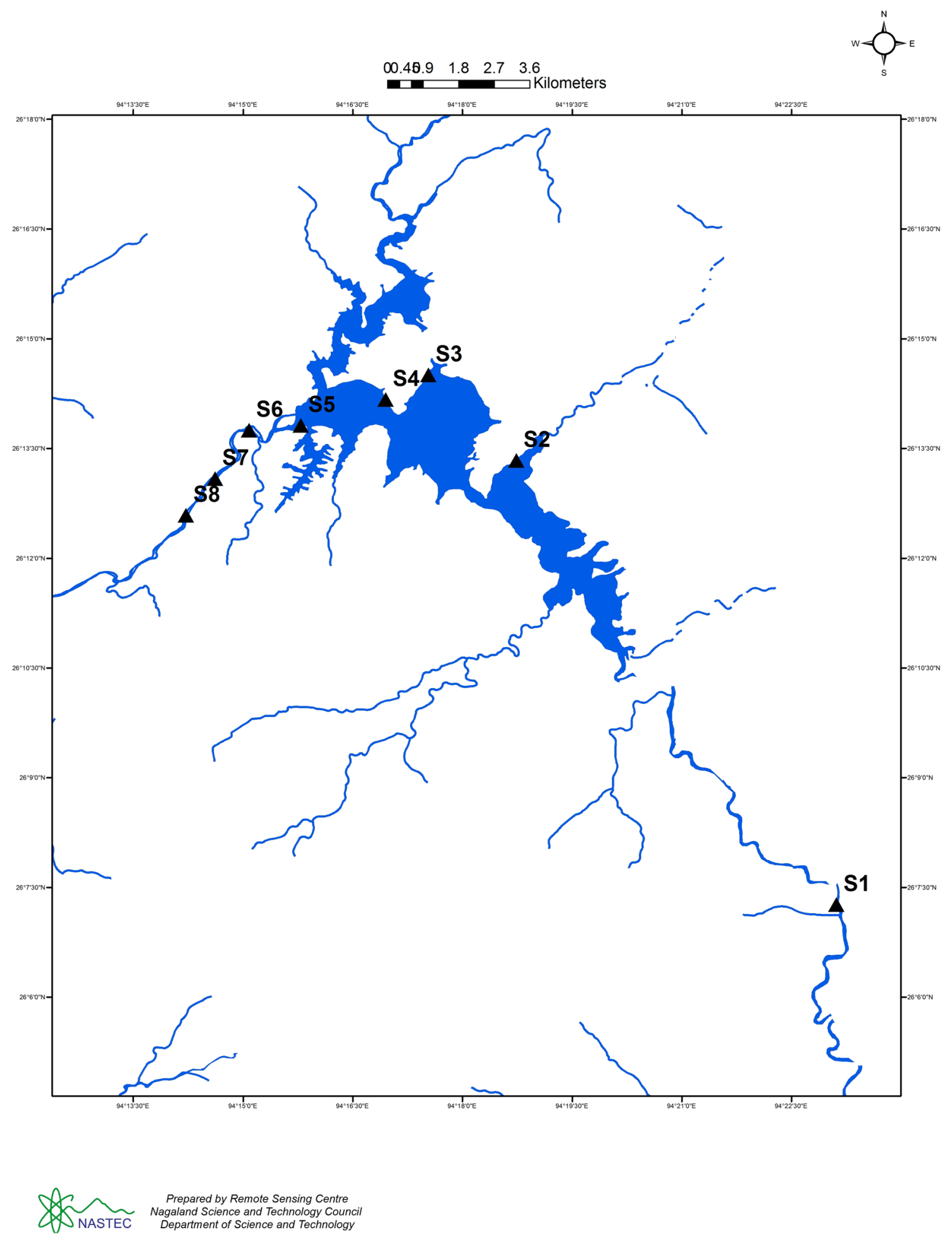

Fig. 2 Map indicating the sampling stations located along Doyang River

et al. 2017). The mean values of $\mathrm{pH}$ from all the sampling stations during PRM, MON and POM were found to be $8.09 \pm 0.08,7.84 \pm 0.06$ and $6.93 \pm 0.06$. In natural water, the common range of $\mathrm{pH}$ falls within 6-8 (Thakre et al.
2010); a similar range of values has also been observed of the current study as well. Electrical conductivity (EC) is an indirect measure of total dissolved salts. The presence of these salts greatly affects the taste and acceptance of the 
Table 2 Water Quality Index (WQI) range, status and possible usage of water sample (Brown et al. 1972)

\begin{tabular}{lll}
\hline WQI range & Water quality status (WQS) & Probable usage \\
\hline $0-25$ & Excellent water quality & Drinking, irrigation and industrial purpose \\
$26-50$ & Good water quality & Drinking, irrigation and industrial purpose \\
$51-75$ & Poor water quality & Irrigation and industrial purpose \\
$76-100$ & Very poor water quality & For irrigation purpose \\
Above 100 & Unsuitable for drinking purpose & Proper treatment required for any kind of usage \\
\hline
\end{tabular}

Table 3 Seasonal mean value, range and statistical variation of water quality parameters of Doyang River

\begin{tabular}{|c|c|c|c|c|c|c|}
\hline \multirow{2}{*}{ Parameters } & \multicolumn{2}{|c|}{ Pre-monsoon (PRM) } & \multicolumn{2}{|c|}{ Monsoon (MON) } & \multicolumn{2}{|c|}{ Post-monsoon (POM) } \\
\hline & Range & Mean \pm SD & Range & Mean \pm SD & Range & Mean \pm SD \\
\hline $\mathrm{pH}$ & $7.86-8.21$ & $8.09 \pm 0.08$ & $7.41-8.29$ & $7.84 \pm 0.06$ & $6.75-7.14$ & $6.93 \pm 0.06$ \\
\hline $\mathrm{EC}$ & $171.32-271.49$ & $188.67 \pm 0.40$ & $144.03-171.23$ & $151.50 \pm 0.24$ & $139.42-214.74$ & $155.05 \pm 0.28$ \\
\hline TDS & $84-134.42$ & $93.95 \pm 0.62$ & $64-80.09$ & $70.35 \pm 0.46$ & $70.84-111.50$ & $79.17 \pm 0.45$ \\
\hline $\mathrm{TH}$ & $74.92-111.33$ & $82.39 \pm 0.89$ & $67.17-79.34$ & $72.52 \pm 0.80$ & $63.50-97.50$ & $70.25 \pm 0.81$ \\
\hline $\mathrm{T} A$ & $104.17-141.25$ & $111.05 \pm 1.62$ & $77.50-100.84$ & $82.87 \pm 1.67$ & $87.09-131.67$ & $96.36 \pm 1.71$ \\
\hline $\mathrm{Ca}^{2+}$ & $15.36-23.11$ & $16.79 \pm 0.37$ & $11.09-16.10$ & $12.99 \pm 0.33$ & $12.43-22.45$ & $14.42 \pm 0.38$ \\
\hline $\mathrm{Mg}^{2+}$ & $8.89-13.03$ & $9.90 \pm 0.22$ & $8.66-10.88$ & $9.72 \pm 0.21$ & $7.80-10.13$ & $8.35 \pm 0.20$ \\
\hline $\mathrm{Cl}^{-}$ & $16.69-24.61$ & $19.07 \pm 0.64$ & $14.55-17.51$ & $16.41 \pm 0.61$ & $18.46-22.72$ & $20.01 \pm 0.68$ \\
\hline $\mathrm{NO}_{3}^{-}$ & $0.56-0.81$ & $0.65 \pm 0.01$ & $0.49-0.71$ & $0.64 \pm 0.02$ & $0.63-0.84$ & $0.72 \pm 0.02$ \\
\hline $\mathrm{SO}_{4}^{2-}$ & $15.45-21.63$ & $16.66 \pm 0.06$ & $12.42-16.94$ & $14.60 \pm 0.04$ & $10.72-18.05$ & $12.17 \pm 0.05$ \\
\hline DO & $10.02-11.38$ & $10.56 \pm 0.15$ & $7.75-10.61$ & $9.12 \pm 0.14$ & $8.26-9.68$ & $9.03 \pm 0.11$ \\
\hline BOD & $0.88-2.96$ & $1.68 \pm 0.08$ & $1.22-3.34$ & $2.18 \pm 0.09$ & $1.72-3.02$ & $2.29 \pm 0.08$ \\
\hline
\end{tabular}

All the parameters are in milligrams per liter except for $\mathrm{pH}$ and $\mathrm{EC}(\mu \mathrm{S} / \mathrm{cm})$

water as potable to the users (Pradeep 1998). Observed mean EC of Doyang River was found to be $188.67 \pm 0.40 \mu \mathrm{S} / \mathrm{cm}$ during PRM, $151.50 \pm 0.24 \mu \mathrm{S} / \mathrm{cm}$ during the MON and $155.05 \pm 0.28 \mu \mathrm{S} / \mathrm{cm}$ in the POM. Season wise a maximum range of 171.32-271.49 $\mu \mathrm{S} / \mathrm{cm}$ was observed in PRM across the different stations (Yogendra and Puttaiah 2008). Total dissolved solids (TDS) measure the dissolved particle present in the water sample and indicate the general nature of water quality or salinity. The values recorded were all under the desirable limits of $500 \mathrm{mg} / \mathrm{l}$ (BIS) with a maximum in PRM season $(93.95 \pm 0.62 \mathrm{mg} / \mathrm{l})$. The MON season observed the least mean values of $70.35 \pm 0.46 \mathrm{mg} / \mathrm{l}$. Total alkalinity (TA) recorded the highest average value of $111.05 \mathrm{mg} / \mathrm{l}$ during the PRM ranging between 104.17 and $141.25 \mathrm{mg} / \mathrm{l}$. However, there was a significant decrease in TA in the monsoon with the mean value of $82.87 \pm 1.67 \mathrm{mg} / \mathrm{l}$. This may be attributed to the influx of fresh water into the river system causing dilution (Chatterjee and Raziuddin 2002). In natural water, total hardness (TH) is contributed mainly by dissolved calcium and magnesium ions (Ikomi and Emuh 2000), with all other divalent cations contributing to its concentration. The majority of its source is contributed by the surrounding rocks of the water bodies. The maximum mean concentration of calcium observed was $16.79 \pm 0.37 \mathrm{mg} / \mathrm{l}$ in PRM with values ranging from 15.36 to $23.11 \mathrm{mg} / \mathrm{l}$. The increase in temperature, low level of water and other domestic waste may have contributed toward its higher concentration (Devi et al. 2015) during the PRM. Magnesium in natural water may be attributed to chemistry of the geological composition of the river bedrock. A mean value of $9.90 \pm 0.21 \mathrm{mg} / \mathrm{l}$, $9.72 \pm 0.21 \mathrm{mg} / \mathrm{l}$ and $8.35 \pm 0.20 \mathrm{mg} / \mathrm{l}$ was recorded during the PRM, MON and POM, respectively. No significant variation was observed in all the three seasons studied. Total hardness $(\mathrm{TH})$ did not show much variation in their concentration in all three seasons. The mean values observed during the PRM, MON and POM seasons were $82.39 \pm 0.89 \mathrm{mg} / \mathrm{l}$, $72.52 \pm 0.80 \mathrm{mg} / \mathrm{l}$ and $70.25 \pm 0.81 \mathrm{mg} / \mathrm{l}$, respectively, and generally fall under the category of moderately hard water (Bora and Goswami 2017). Chloride occurs naturally in all types of water; however, its main contributing sources are runoff of inorganic fertilizers from agricultural fields, sewage discharge, etc. The chloride content of the sample was found to be well within the permissible levels of $250 \mathrm{mg} / \mathrm{l}$. Its highest concentration was recorded during the POM (average value of $20.01 \pm 0.68 \mathrm{mg} / \mathrm{l}$ ) and least (average concentration of $16.41 \mathrm{mg} / \mathrm{l}$ ) during the MON. Nitrate is found in surface waters as a result of sewage, fertilizer runoff from agricultural land, etc. Excess of nitrate can cause eutrophication 
(WHO 1998) resulting in the death of aquatic animals and serious health hazards. The highest recorded mean value of nitrate was found to be $0.72 \pm 0.02 \mathrm{mg} / \mathrm{l}$ during the POM. However, in the present study, the concentration of nitrate recorded relatively low with values ranging from 0.49 to $0.84 \mathrm{mg} / \mathrm{l}$ (Ewaid 2017). Sulfate naturally occurs in surface water as a result of weathering of igneous and sedimentary rock. Other sources may be leachate from abandoned mines, air deposition from the combustion of fossil fuels and industrial wastewater. The mean concentration of sulfate recorded during the study period was $16.66 \pm 0.06 \mathrm{mg} / \mathrm{l}$, $14.60 \pm 0.04 \mathrm{mg} / \mathrm{l}$ and $12.17 \pm 0.05 \mathrm{mg} / \mathrm{l}$ in PRM, MON and $\mathrm{POM}$, respectively. The PRM recorded the maximum sulfate

Table 4 Relative weights $\left(W_{i}\right)$ of different parameters and their standards used for WQI determination

\begin{tabular}{lll}
\hline Parameters & $\begin{array}{l}\text { ICMR/BIS standards } \\
\left(S_{i}\right)\end{array}$ & Unit weight $\left(W_{i}\right)$ \\
\hline $\mathrm{pH}$ & $6.5-8.5$ & 0.192 \\
$\mathrm{EC}$ & 300 & 0.005 \\
$\mathrm{TDS}$ & 500 & 0.003 \\
$\mathrm{~T} \mathrm{H}$ & 300 & 0.005 \\
$\mathrm{~T} \mathrm{~A}$ & 120 & 0.014 \\
$\mathrm{Ca}^{2+}$ & 75 & 0.022 \\
$\mathrm{Mg}^{2+}$ & 30 & 0.054 \\
$\mathrm{Cl}^{-}$ & 250 & 0.007 \\
$\mathrm{NO}_{3}^{-}$ & 45 & 0.036 \\
$\mathrm{SO}_{4}{ }^{2-}$ & 150 & 0.011 \\
$\mathrm{DO}^{-}$ & 5 & 0.326 \\
$\mathrm{BOD}^{2}$ & 5 & 0.326 \\
\hline$W_{i}=1.000$ & & \\
\hline
\end{tabular}

concentration with values ranging from 15.45 to $21.63 \mathrm{mg} / \mathrm{l}$; nevertheless, all the observed values were within the tolerable limits of $150 \mathrm{mg} / \mathrm{l}$ (Yisa and Jimoh 2010). Dissolved oxygen (DO) is the measurement of the amount of oxygen dissolved in water and is a direct indicator of water quality. In a healthy water body that ensures good water quality, DO must be $>4 \mathrm{mg} / \mathrm{l}$ (Prasad and Bose 2001). DO along Doyang River was recorded significantly high from all the stations throughout the study period. The highest concentration of DO was observed during the PRM season range from 10.02 to $11.38 \mathrm{mg} / \mathrm{l}$ with a mean value of $10.56 \pm 0.15 \mathrm{mg} / \mathrm{l}$. The turbulent nature of the water bodies, photosynthesis and a decrease in temperature might have resulted in the increased concentration of DO (Bouslah et al. 2017). Biological oxygen demand (BOD) determines the strength of oxygen to stabilize domestic and industrial waste. A higher value of BOD levels represents a higher level of organic pollution (Patel et al. 1983) indicating higher organic pollution in a water sample. Observed BOD in PRM, MON and POM was $1.68 \pm 0.08 \mathrm{mg} / \mathrm{l}, 2.18 \pm 0.09 \mathrm{mg} / \mathrm{l}$ and $2.29 \pm 0.08 \mathrm{mg} / \mathrm{l}$, respectively. The low level of BOD in the present study indicates less organic matter in the water sample to be oxidized by microorganisms (Singh et al. 2016). All the twelve physicochemical parameters of water analyzed were well within the permissible limits of drinking water given by BIS (2003) and ICMR (1975).

\section{Water Quality Index (WQI) calculation}

The calculation of WQI using Weighted Arithmetic Index involves the estimation of 'unit weight' assigned to each physicochemical parameter selected. Different units and dimensions of the selected parameters are transformed into

Table 5 Calculation of WQI at station 1 (S 1)

\begin{tabular}{|c|c|c|c|c|c|c|c|c|c|}
\hline \multirow[t]{2}{*}{ Parameters } & \multicolumn{3}{|c|}{ Pre-monsoon (PRM) } & \multicolumn{3}{|l|}{ Monsoon (MON) } & \multicolumn{3}{|c|}{ Post-monsoon (POM) } \\
\hline & $V_{i}$ & $Q_{i}$ & $W_{i}^{*} Q_{i}$ & $V_{i}$ & $Q_{i}$ & $W_{i}^{*} Q_{i}$ & $V_{i}$ & $Q_{i}$ & $W_{i}^{*} Q_{i}$ \\
\hline $\mathrm{pH}$ & 8.21 & 80.6667 & 15.4512 & 7.74 & 49.3333 & 9.4495 & 7.14 & 9.3333 & 1.7877 \\
\hline $\mathrm{EC}$ & 271.49 & 90.4967 & 0.4911 & 171.23 & 57.0767 & 0.3098 & 214.74 & 71.5800 & 0.3885 \\
\hline TDS & 134.42 & 26.8840 & 0.0875 & 80.09 & 16.0180 & 0.0522 & 111.5 & 22.3000 & 0.0726 \\
\hline $\mathrm{T} \mathrm{H}$ & 111.33 & 37.1100 & 0.2014 & 76 & 25.3333 & 0.1375 & 97.5 & 32.5000 & 0.1764 \\
\hline $\mathrm{T} \mathrm{A}$ & 141.25 & 117.7083 & 1.5970 & 100.84 & 84.0333 & 1.1401 & 131.67 & 109.7250 & 1.4887 \\
\hline $\mathrm{Ca}^{2+}$ & 23.11 & 30.8133 & 0.6689 & 16.1 & 21.4667 & 0.4660 & 22.45 & 29.9333 & 0.6498 \\
\hline $\mathrm{Mg}^{2+}$ & 13.03 & 43.4333 & 2.3572 & 8.66 & 28.8667 & 1.5666 & 10.13 & 33.7667 & 1.8325 \\
\hline $\mathrm{Cl}^{-}$ & 24.61 & 9.8440 & 0.0641 & 17.43 & 6.9720 & 0.0454 & 22.72 & 9.0880 & 0.0592 \\
\hline $\mathrm{NO}_{3}^{-}$ & 0.81 & 1.8000 & 0.0651 & 0.71 & 1.5778 & 0.0571 & 0.84 & 1.8667 & 0.0675 \\
\hline $\mathrm{SO}_{4}{ }^{2-}$ & 21.63 & 14.4200 & 0.1565 & 16.03 & 10.6867 & 0.1160 & 18.05 & 12.0333 & 0.1306 \\
\hline DO & 10.39 & 43.8542 & 14.2800 & 9.33 & 54.8958 & 17.8755 & 9.68 & 51.2500 & 16.6883 \\
\hline \multirow[t]{3}{*}{ BOD } & 1.91 & 38.2000 & 12.4389 & 1.66 & 33.2000 & 10.8108 & 2.4 & 48.0000 & 15.6300 \\
\hline & $\sum W_{i} Q_{i}=47.8591$ & & & $\sum W_{i} Q_{i}=42.0264$ & & & $\sum W_{i} Q_{i}=38.9^{\prime}$ & & \\
\hline & $\mathrm{WQI}=47.86$ & & & $\mathrm{WQI}=42.03$ & & & $\mathrm{WQI}=38.97$ & & \\
\hline
\end{tabular}


Table 6 Calculation of WQI at station 2 (S 2)

\begin{tabular}{|c|c|c|c|c|c|c|c|c|c|}
\hline \multirow[t]{2}{*}{ Parameters } & \multicolumn{3}{|c|}{ Pre-monsoon (PRM) } & \multicolumn{3}{|l|}{ Monsoon (MON) } & \multicolumn{3}{|c|}{ Post-monsoon (POM) } \\
\hline & $V_{i}$ & $Q_{i}$ & $W_{i}^{*} Q_{i}$ & $V_{i}$ & $Q_{i}$ & $W_{i}^{*} Q_{i}$ & $V_{i}$ & $Q_{i}$ & $W_{i}^{*} Q_{i}$ \\
\hline $\mathrm{pH}$ & 7.86 & 57.3333 & 10.9819 & 7.83 & 55.3333 & 10.5988 & 7.12 & 8.0000 & 1.5324 \\
\hline $\mathrm{EC}$ & 194.26 & 64.7533 & 0.3514 & 148.37 & 49.4567 & 0.2684 & 145.71 & 48.5700 & 0.2636 \\
\hline TDS & 97.92 & 19.5840 & 0.0638 & 69 & 13.8000 & 0.0449 & 74.67 & 14.9340 & 0.0486 \\
\hline $\mathrm{T} \mathrm{H}$ & 86.33 & 28.7767 & 0.1562 & 72.34 & 24.1133 & 0.1309 & 66.17 & 22.0567 & 0.1197 \\
\hline $\mathrm{T} \mathrm{A}$ & 110.42 & 92.0167 & 1.2485 & 78.75 & 65.6250 & 0.8904 & 89.17 & 74.3083 & 1.0082 \\
\hline $\mathrm{Ca}^{2+}$ & 17.17 & 22.8933 & 0.4970 & 12.69 & 16.9200 & 0.3673 & 13.63 & 18.1733 & 0.3945 \\
\hline $\mathrm{Mg}^{2+}$ & 10.52 & 35.0667 & 1.9031 & 9.99 & 33.3000 & 1.8072 & 7.8 & 26.0000 & 1.4110 \\
\hline $\mathrm{Cl}^{-}$ & 19.88 & 7.9520 & 0.0518 & 17.51 & 7.0040 & 0.0456 & 18.58 & 7.4320 & 0.0484 \\
\hline $\mathrm{NO}_{3}^{-}$ & 0.61 & 1.3556 & 0.0490 & 0.73 & 1.6222 & 0.0587 & 0.79 & 1.7556 & 0.0635 \\
\hline $\mathrm{SO}_{4}{ }^{2-}$ & 16.94 & 11.2933 & 0.1226 & 13.53 & 9.0200 & 0.0979 & 11.27 & 7.5133 & 0.0816 \\
\hline DO & 10.05 & 47.3958 & 15.4333 & 9.78 & 50.2083 & 16.3491 & 8.79 & 60.5208 & 19.7071 \\
\hline \multirow[t]{3}{*}{ BOD } & 2.96 & 59.2000 & 19.2770 & 3.24 & 64.8000 & 21.1005 & 3.02 & 60.4000 & 19.6678 \\
\hline & $\sum W_{i} Q_{i}=50.1355$ & & & $\sum W_{i} Q_{i}=51.7598$ & & & $\sum W_{i} Q_{i}=44.3464$ & & \\
\hline & $\mathrm{WQI}=50.14$ & & & $\mathrm{WQI}=51.76$ & & & $\mathrm{WQI}=44.35$ & & \\
\hline
\end{tabular}

Table 7 Calculation of WQI at station 3 (S 3)

\begin{tabular}{|c|c|c|c|c|c|c|c|c|c|}
\hline \multirow[t]{2}{*}{ Parameters } & \multicolumn{3}{|c|}{ Pre-monsoon (PRM) } & \multicolumn{3}{|l|}{ Monsoon (MON) } & \multicolumn{3}{|c|}{ Post-monsoon (POM) } \\
\hline & $V_{i}$ & $Q_{i}$ & $W_{i}^{*} Q_{i}$ & $V_{i}$ & $Q_{i}$ & $W_{i}^{*} Q_{i}$ & $V_{i}$ & $Q_{i}$ & $W_{i}^{*} Q_{i}$ \\
\hline $\mathrm{pH}$ & 8.1 & 73.3333 & 14.0466 & 8.11 & 74.0000 & 14.1743 & 6.87 & -8.6667 & -1.6601 \\
\hline $\mathrm{EC}$ & 176.53 & 58.8433 & 0.3193 & 153.01 & 51.0033 & 0.2768 & 143.97 & 47.9900 & 0.2604 \\
\hline TDS & 89.25 & 17.8500 & 0.0581 & 70.42 & 14.0840 & 0.0459 & 72 & 14.4000 & 0.0469 \\
\hline $\mathrm{T} \mathrm{H}$ & 79 & 26.3333 & 0.1429 & 71.17 & 23.7233 & 0.1287 & 65.17 & 21.7233 & 0.1179 \\
\hline $\mathrm{T} \mathrm{A}$ & 107.59 & 89.6583 & 1.2165 & 77.5 & 64.5833 & 0.8762 & 92.92 & 77.4333 & 1.0506 \\
\hline $\mathrm{Ca}^{2+}$ & 15.98 & 21.3067 & 0.4625 & 12.52 & 16.6933 & 0.3624 & 13.03 & 17.3733 & 0.3771 \\
\hline $\mathrm{Mg}^{2+}$ & 9.5 & 31.6667 & 1.7186 & 9.66 & 32.2000 & 1.7475 & 7.92 & 26.4000 & 1.4328 \\
\hline $\mathrm{Cl}^{-}$ & 18.68 & 7.4720 & 0.0487 & 15.98 & 6.3920 & 0.0416 & 18.46 & 7.3840 & 0.0481 \\
\hline $\mathrm{NO}_{3}^{-}$ & 0.59 & 1.3111 & 0.0474 & 0.59 & 1.3111 & 0.0474 & 0.7 & 1.5556 & 0.0563 \\
\hline $\mathrm{SO}_{4}{ }^{2-}$ & 15.98 & 10.6533 & 0.1156 & 12.92 & 8.6133 & 0.0935 & 10.89 & 7.2600 & 0.0788 \\
\hline DO & 10.09 & 46.9792 & 15.2976 & 9.38 & 54.3750 & 17.7059 & 8.79 & 60.5208 & 19.7071 \\
\hline BOD & 2.07 & 41.4000 & 13.4809 & 2.84 & 56.8000 & 18.4955 & 2.18 & 43.6000 & 14.1973 \\
\hline & $\sum W_{i} Q_{i}=46.9548$ & & & $\sum W_{i} Q_{i}=53.9958$ & & & $\sum W_{i} Q_{i}=35.7132$ & & \\
\hline & $\mathrm{WQI}=46.95$ & & & $\mathrm{WQI}=53.10$ & & & $\mathrm{WQI}=35.71$ & & \\
\hline
\end{tabular}

a common scale using the assigning units. Table 4 shows the drinking water quality standards and the unit weights assigned to each parameter used for the calculation of WQI. Considering the significance of water quality assessment and their impact on the value of WQI, a maximum weightage of 0.366 is assigned to both DO and BOD. Tables 5, 6, 7, 8, 9, 10, 11 and 12 depict the values observed for the selected physicochemical parameters from the eight sampling stations during each season and their corresponding WQI values. $\mathrm{pH}, \mathrm{DO}$ and BOD were found to be the most significant parameters in the WQI scores worked out.

The overall values of WQI of the water samples from all the eight sampling stations for each season are presented in
Table 13. WQI were observed to have a positive relationship with the seasonal changes. Maximum WQI values were recorded during MON from all the eight stations followed by PRM and POM. A similar finding has also been reported by researchers like Singh and Kamal (2014), Bora and Goswami (2017) in their studies of assessment of surface water quality status. An average value of WQI for all the stations during PRM, MON and POM was 42.95, 47.13 and 36.66, respectively, as presented in Table 14. This result indicates that the quality of the water samples from all the stations falls under the class of good water samples $(25<\mathrm{WQI}<50)$ suitable for drinking, irrigation and industrial purpose (Fig. 3). Ranges of WQI values from all the eight stations 
Table 8 Calculation of WQI at station 4 (S 4)

\begin{tabular}{|c|c|c|c|c|c|c|c|c|c|}
\hline \multirow[t]{2}{*}{ Parameters } & \multicolumn{3}{|c|}{ Pre-monsoon (PRM) } & \multicolumn{3}{|l|}{ Monsoon (MON) } & \multicolumn{3}{|c|}{ Post-monsoon (POM) } \\
\hline & $V_{i}$ & $Q_{i}$ & $W_{i}^{*} Q_{i}$ & $V_{i}$ & $Q_{i}$ & $W_{i}^{*} Q_{i}$ & $V_{i}$ & $Q_{i}$ & $W_{i}{ }^{*} Q_{i}$ \\
\hline $\mathrm{pH}$ & 8.08 & 72.0000 & 13.7912 & 8.29 & 86.0000 & 16.4728 & 6.86 & -9.3333 & -1.7877 \\
\hline $\mathrm{EC}$ & 175.91 & 58.6367 & 0.3182 & 144.03 & 48.0100 & 0.2606 & 140.23 & 46.7433 & 0.2537 \\
\hline TDS & 86.75 & 17.3500 & 0.0565 & 67 & 13.4000 & 0.0436 & 71.5 & 14.3000 & 0.0466 \\
\hline $\mathrm{TH}$ & 77.67 & 25.8900 & 0.1405 & 70.33 & 23.4433 & 0.1272 & 63.5 & 21.1667 & 0.1149 \\
\hline $\mathrm{T} A$ & 107.5 & 89.5833 & 1.2154 & 83.75 & 69.7917 & 0.9469 & 87.09 & 72.5750 & 0.9847 \\
\hline $\mathrm{Ca}^{2+}$ & 15.57 & 20.7600 & 0.4507 & 11.09 & 14.7867 & 0.3210 & 12.43 & 16.5733 & 0.3598 \\
\hline $\mathrm{Mg}^{2+}$ & 9.54 & 31.8000 & 1.7258 & 10.08 & 33.6000 & 1.8235 & 7.92 & 26.4000 & 1.4328 \\
\hline $\mathrm{Cl}^{-}$ & 19.41 & 7.7640 & 0.0506 & 14.55 & 5.8200 & 0.0379 & 19.17 & 7.6680 & 0.0499 \\
\hline $\mathrm{NO}_{3}^{-}$ & 0.56 & 1.2444 & 0.0450 & 0.49 & 1.0889 & 0.0394 & 0.63 & 1.4000 & 0.0507 \\
\hline $\mathrm{SO}_{4}{ }^{2-}$ & 15.66 & 10.4400 & 0.1133 & 12.8 & 8.5333 & 0.0926 & 10.75 & 7.1667 & 0.0778 \\
\hline DO & 10.2 & 45.8333 & 14.9245 & 10.61 & 41.5625 & 13.5338 & 8.64 & 62.0833 & 20.2159 \\
\hline \multirow[t]{3}{*}{ BOD } & 1.38 & 27.6000 & 8.9873 & 3.34 & 66.8000 & 21.7518 & 1.72 & 34.4000 & 11.2015 \\
\hline & $\sum W_{i} Q_{i}=41.8190$ & & & $\sum W_{i} Q_{i}=55.4512$ & & & $\sum W_{i} Q_{i}=33.0004$ & & \\
\hline & $\mathrm{WQI}=41.82$ & & & $\mathrm{WQI}=55.45$ & & & $\mathrm{WQI}=33.00$ & & \\
\hline
\end{tabular}

Table 9 Calculation of WQI at station 5 (S 5)

\begin{tabular}{|c|c|c|c|c|c|c|c|c|c|}
\hline \multirow[t]{2}{*}{ Parameters } & \multicolumn{3}{|c|}{ Pre-monsoon (PRM) } & \multicolumn{3}{|l|}{ Monsoon (MON) } & \multicolumn{3}{|c|}{ Post-monsoon (POM) } \\
\hline & $V_{i}$ & $Q_{i}$ & $W_{i}^{*} Q_{i}$ & $V_{i}$ & $Q_{i}$ & $W_{i}^{*} Q_{i}$ & $V_{i}$ & $Q_{i}$ & $W_{i}^{*} Q_{i}$ \\
\hline $\mathrm{pH}$ & 8.13 & 75.3333 & 14.4297 & 8.22 & 81.3333 & 15.5789 & 6.85 & -10.0000 & -1.9154 \\
\hline $\mathrm{EC}$ & 171.32 & 57.1067 & 0.3099 & 134.28 & 44.7600 & 0.2429 & 139.42 & 46.4733 & 0.2522 \\
\hline TDS & 86.42 & 17.2840 & 0.0563 & 64 & 12.8000 & 0.0417 & 70.84 & 14.1680 & 0.0461 \\
\hline $\mathrm{T} \mathrm{H}$ & 76.67 & 25.5567 & 0.1387 & 67.17 & 22.3900 & 0.1215 & 63.84 & 21.2800 & 0.1155 \\
\hline $\mathrm{T} A$ & 104.17 & 86.8083 & 1.1778 & 79.59 & 66.3250 & 0.8999 & 87.92 & 73.2667 & 0.9941 \\
\hline $\mathrm{Ca}^{2+}$ & 15.7 & 20.9333 & 0.4544 & 11.15 & 14.8667 & 0.3227 & 12.49 & 16.6533 & 0.3615 \\
\hline $\mathrm{Mg}^{2+}$ & 9.3 & 31.0000 & 1.6824 & 9.58 & 31.9333 & 1.7331 & 7.88 & 26.2667 & 1.4255 \\
\hline $\mathrm{Cl}^{-}$ & 18.23 & 7.2920 & 0.0475 & 16.8 & 6.7200 & 0.0438 & 18.7 & 7.4800 & 0.0487 \\
\hline $\mathrm{NO}_{3}^{-}$ & 0.66 & 1.4667 & 0.0531 & 0.6 & 1.3333 & 0.0482 & 0.63 & 1.4000 & 0.0507 \\
\hline $\mathrm{SO}_{4}{ }^{2-}$ & 15.56 & 10.3733 & 0.1126 & 12.42 & 8.2800 & 0.0899 & 10.72 & 7.1467 & 0.0776 \\
\hline DO & 10.02 & 47.7083 & 15.5350 & 10.12 & 46.6667 & 15.1959 & 8.26 & 66.0417 & 21.5048 \\
\hline BOD & 1.39 & 27.8000 & 9.0524 & 2.63 & 52.6000 & 17.1279 & 1.78 & 35.6000 & 11.5923 \\
\hline & $\sum W_{i} Q_{i}=43.0498$ & & & $\sum W_{i} Q_{i}=51.4463$ & & & $\sum W_{i} Q_{i}=34.5535$ & & \\
\hline & $\mathrm{WQI}=43.05$ & & & $\mathrm{WQI}=51.45$ & & & $\mathrm{WQI}=34.55$ & & \\
\hline
\end{tabular}

during PRM, MON and POM were: 35.89 (S 6)-50.14 (S 2), 40.77 (S 7)-55.45 (S 4) and 33.00 (S 4)-44.35 (S 2), respectively (Table 13). In all the stations, both PRM and POM showed good water quality status. However, MON showed poor water quality status at stations 2, 3, 4 and 5 located around the vicinity of the hydroelectric dam.

The WQI value showed a mixed pattern of changes in all the seasons (Fig. 4). WQI of the upstream stations from 1 to 5 is higher than the downstream stations, i.e., 6-8 showing the decrease in pollution level while moving downstream of the river. Such observation was also made by Bora and Goswami (2017) in their studies of water quality assessment of Kolong River, Assam, where the water samples showed a decreasing pollution trend further downstream. Workers like Ewaid (2017) have observed better water quality status in upstream than downstream due to a decrease in water and accumulation of contaminants along the downstream of the river. However, the above case is not the same in the present study. This could be due to the absorption of contaminants by healthy riparian vegetation that is present along the downstream of the river. Despite witnessing several landuse practices along the riparian zones, there also observed abundant growth of riparian vegetation that might have positively mitigated in controlling pollution of the river. Workers like Othman et al. (2012) and Naubi et al. (2016) have 
Table 10 Calculation of WQI at station 6 (S 6)

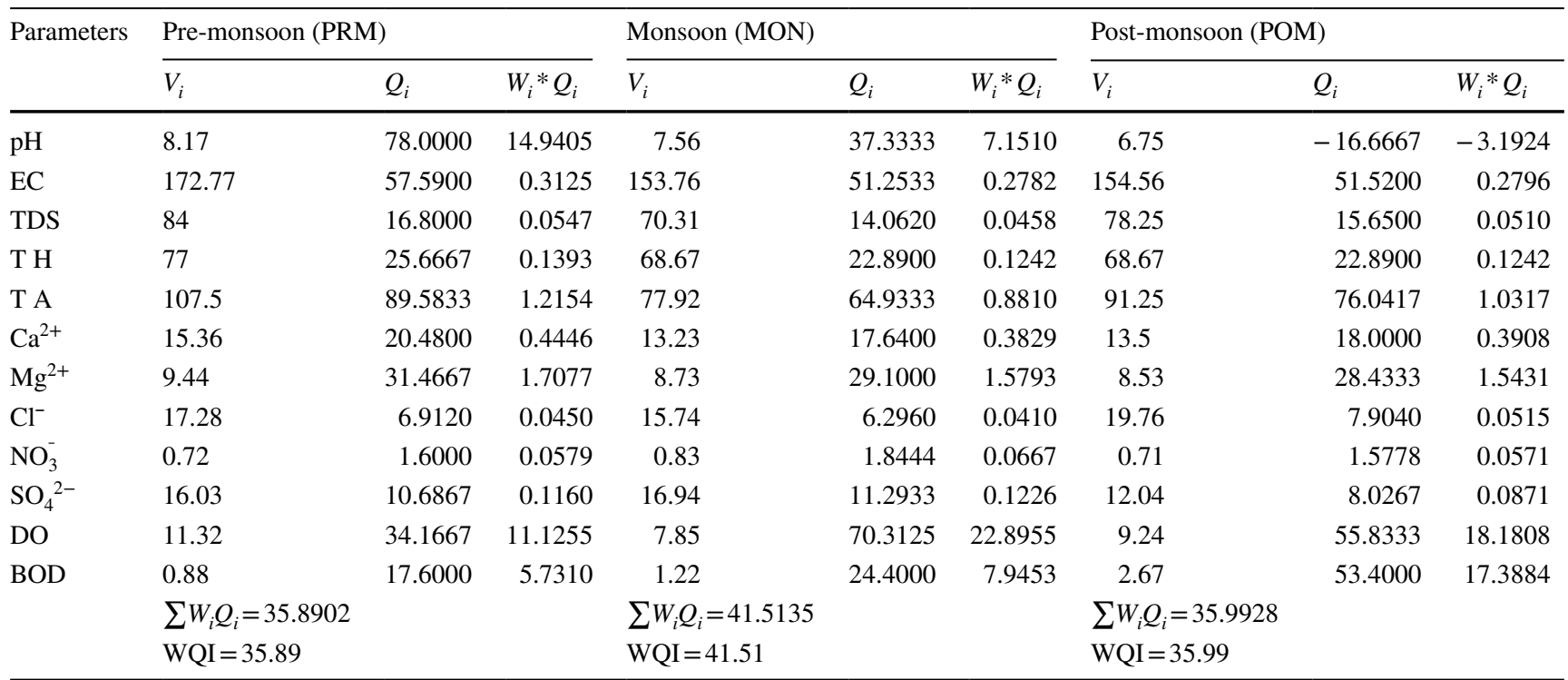

Table 11 Calculation of WQI at station 7 (S 7)

\begin{tabular}{|c|c|c|c|c|c|c|c|c|c|}
\hline \multirow[t]{2}{*}{ Parameters } & \multicolumn{3}{|c|}{ Pre-monsoon (PRM) } & \multicolumn{3}{|l|}{ Monsoon (MON) } & \multicolumn{3}{|c|}{ Post-monsoon (POM) } \\
\hline & $V_{i}$ & $Q_{i}$ & $W_{i}^{*} Q_{i}$ & $V_{i}$ & $Q_{i}$ & $W_{i}^{*} Q_{i}$ & $V_{i}$ & $Q_{i}$ & $W_{i}^{*} Q_{i}$ \\
\hline $\mathrm{pH}$ & 8.06 & 70.6667 & 13.5358 & 7.41 & 27.3333 & 5.2355 & 6.99 & -0.6667 & -0.1277 \\
\hline $\mathrm{EC}$ & 173.43 & 57.8100 & 0.3137 & 154.14 & 51.3800 & 0.2788 & 151.09 & 50.3633 & 0.2733 \\
\hline TDS & 87.17 & 17.4340 & 0.0568 & 70.83 & 14.1660 & 0.0461 & 77.58 & 15.5160 & 0.0505 \\
\hline $\mathrm{T} \mathrm{H}$ & 74.92 & 24.9733 & 0.1355 & 79.34 & 26.4467 & 0.1435 & 67.67 & 22.5567 & 0.1224 \\
\hline $\mathrm{T} \mathrm{A}$ & 104.58 & 87.1500 & 1.1824 & 81.25 & 67.7083 & 0.9186 & 92.5 & 77.0833 & 1.0458 \\
\hline $\mathrm{Ca}^{2+}$ & 15.5 & 20.6667 & 0.4486 & 13.76 & 18.3467 & 0.3983 & 13.63 & 18.1733 & 0.3945 \\
\hline $\mathrm{Mg}^{2+}$ & 8.97 & 29.9000 & 1.6227 & 10.88 & 36.2667 & 1.9682 & 8.24 & 27.4667 & 1.4906 \\
\hline $\mathrm{Cl}^{-}$ & 16.69 & 6.6760 & 0.0435 & 16.21 & 6.4840 & 0.0422 & 20.95 & 8.3800 & 0.0546 \\
\hline $\mathrm{NO}_{3}^{-}$ & 0.63 & 1.4000 & 0.0507 & 0.6 & 1.3333 & 0.0482 & 0.76 & 1.6889 & 0.0611 \\
\hline $\mathrm{SO}_{4}{ }^{2-}$ & 16.02 & 10.6800 & 0.1159 & 16.25 & 10.8333 & 0.1176 & 11.86 & 7.9067 & 0.0858 \\
\hline DO & 10.99 & 37.6042 & 12.2449 & 7.75 & 71.3542 & 23.2347 & 9.4 & 54.1667 & 17.6380 \\
\hline BOD & 1.29 & 25.8000 & 8.4011 & 1.28 & 25.6000 & 8.3360 & 2.2 & 44.0000 & 14.3275 \\
\hline & $\sum W_{i} Q_{i}=38.1517$ & & & $\sum W_{i} Q_{i}=40.7680$ & & & $\sum W_{i} Q_{i}=35.4166$ & & \\
\hline & $\mathrm{WQI}=38.15$ & & & $\mathrm{WQI}=40.77$ & & & $\mathrm{WQI}=35.42$ & & \\
\hline
\end{tabular}

shown encouraging results in the improvement of water quality due to proper management policy and remedial measures. Stations $2-5$ experience an abrupt rise in pollution level as all these stations are located near the vicinity of the hydroelectric dam. The stagnant condition of water bodies due to the presence of hydroelectric dam and different landuse activities around these stations could have contributed to the deteriorating condition of water quality. Particularly at station 1, runoff of bridge construction materials (concrete, asphalt, etc.) from the ongoing construction of national highway bridge (NH-02) across the river and cutting down of riparian hill slope for the same have contributed to the increased concentration of many of the water quality parameters analyzed. The presence of some residential homes in the adjoining areas of station 1 has also played a vital role in influencing the physicochemical parameters of water. Different landuse activities located in the upstream of the river like Jhumming (S3), residential area (S1 and S5) and monoculture like teak plantation (S4) have imposed a serious threat to water quality deterioration. Besides, burning of forest annually for shifting cultivation, felling and logging of 
Table 12 Calculation of WQI at station 8 (S 8)

\begin{tabular}{|c|c|c|c|c|c|c|c|c|c|}
\hline \multirow[t]{2}{*}{ Parameters } & \multicolumn{3}{|c|}{ Pre-monsoon (PRM) } & \multicolumn{3}{|l|}{ Monsoon (MON) } & \multicolumn{3}{|c|}{ Post-monsoon (POM) } \\
\hline & $V_{i}$ & $Q_{i}$ & $W_{i}^{*} Q_{i}$ & $V_{i}$ & $Q_{i}$ & $W_{i}^{*} Q_{i}$ & $V_{i}$ & $Q_{i}$ & $W_{i}^{*} Q_{i}$ \\
\hline $\mathrm{pH}$ & 8.14 & 76.0000 & 14.5574 & 7.57 & 38.0000 & 7.2787 & 6.89 & -7.3333 & -1.4047 \\
\hline $\mathrm{EC}$ & 173.64 & 57.8800 & 0.3141 & 153.16 & 51.0533 & 0.2771 & 150.65 & 50.2167 & 0.2725 \\
\hline TDS & 85.67 & 17.1340 & 0.0558 & 71.17 & 14.2340 & 0.0463 & 77 & 15.4000 & 0.0501 \\
\hline $\mathrm{T} \mathrm{H}$ & 76.17 & 25.3900 & 0.1378 & 75.17 & 25.0567 & 0.1360 & 69.5 & 23.1667 & 0.1257 \\
\hline T A & 105.42 & 87.8500 & 1.1919 & 83.34 & 69.4500 & 0.9423 & 98.34 & 81.9500 & 1.1119 \\
\hline $\mathrm{Ca}^{2+}$ & 15.9 & 21.2000 & 0.4602 & 13.36 & 17.8133 & 0.3867 & 14.17 & 18.8933 & 0.4101 \\
\hline $\mathrm{Mg}^{2+}$ & 8.89 & 29.6333 & 1.6082 & 10.15 & 33.8333 & 1.8362 & 8.36 & 27.8667 & 1.5123 \\
\hline $\mathrm{Cl}^{-}$ & 17.75 & 7.1000 & 0.0462 & 17.04 & 6.8160 & 0.0444 & 21.77 & 8.7080 & 0.0567 \\
\hline $\mathrm{NO}_{3}^{-}$ & 0.62 & 1.3778 & 0.0498 & 0.57 & 1.2667 & 0.0458 & 0.69 & 1.5333 & 0.0555 \\
\hline $\mathrm{SO}_{4}{ }^{2-}$ & 15.45 & 10.3000 & 0.1118 & 15.9 & 10.6000 & 0.1151 & 11.79 & 7.8600 & 0.0853 \\
\hline DO & 11.38 & 33.5417 & 10.9220 & 8.14 & 67.2917 & 21.9119 & 9.4 & 54.1667 & 17.6380 \\
\hline \multirow[t]{3}{*}{ BOD } & 1.58 & 31.6000 & 10.2898 & 1.22 & 24.4000 & 7.9453 & 2.36 & 47.2000 & 15.3695 \\
\hline & $\sum W_{i} Q_{i}=39.7451$ & & & $\sum W_{i} Q_{i}=40.9656$ & & & $\sum W_{i} Q_{i}=35.2832$ & & \\
\hline & $\mathrm{WQI}=39.75$ & & & $\mathrm{WQI}=40.97$ & & & $\mathrm{WQI}=35.28$ & & \\
\hline
\end{tabular}

Table 13 Summary of WQI of Doyang River along with its water quality status (WQS)

\begin{tabular}{|c|c|c|c|c|c|c|}
\hline \multirow[t]{2}{*}{ Sampling station } & \multicolumn{2}{|c|}{ Pre-monsoon (PRM) } & \multicolumn{2}{|c|}{ Monsoon (MON) } & \multicolumn{2}{|c|}{ Post-monsoon (POM) } \\
\hline & WQI & WQS & WQI & WQS & WQI & WQS \\
\hline S 1 & 47.86 & Good & 42.03 & Good & 38.97 & Good \\
\hline S 2 & 50.14 & Poor & 51.76 & Poor & 44.35 & Good \\
\hline S 3 & 46.95 & Good & 53.10 & Poor & 35.71 & Good \\
\hline S 4 & 41.82 & Good & 55.45 & Poor & 33.00 & Good \\
\hline S 5 & 43.05 & Good & 51.45 & Poor & 34.55 & Good \\
\hline S 6 & 35.89 & Good & 41.51 & Good & 35.99 & Good \\
\hline S 7 & 38.15 & Good & 40.77 & Good & 35.42 & Good \\
\hline S 8 & 39.75 & Good & 40.97 & Good & 35.28 & Good \\
\hline
\end{tabular}

Table 14 Seasonal WQI of Doyang River with its water quality status (WQI)

\begin{tabular}{lcc}
\hline Seasons & WQI & WQS \\
\hline Pre-monsoon & 42.95 & Good \\
Monsoon & 47.13 & Good \\
Post-monsoon & 36.66 & Good \\
\hline
\end{tabular}

trees for timber, picnic spot along the river and fishing activities have also exerted much pressure in influencing the water quality of the river. Anthropogenic activities like sewage disposal by the communities residing in the catchment areas, agricultural runoff and unprotected river sites (Yisa and Jimoh 2010, Bouslah et al. 2017 and Shah and Joshi 2017) have also been contributing agents in the deterioration of water quality.

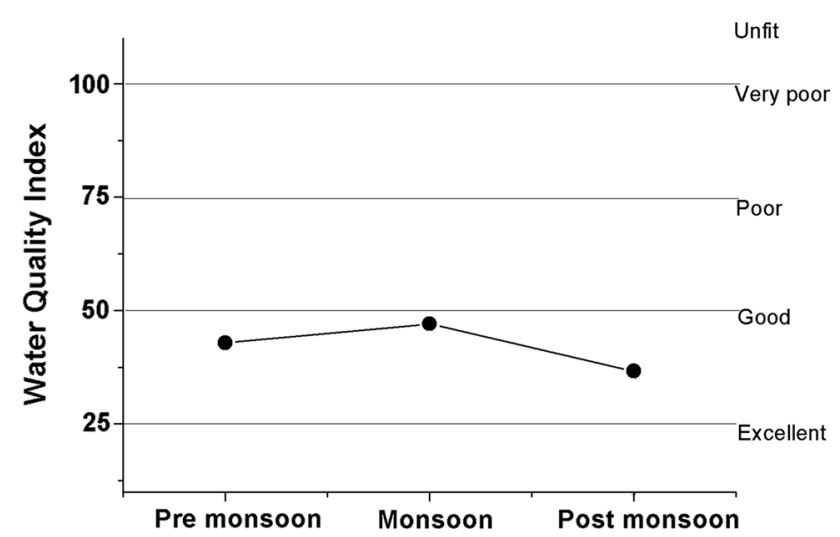

Fig. 3 WQI rating of Doyang River in various seasons 


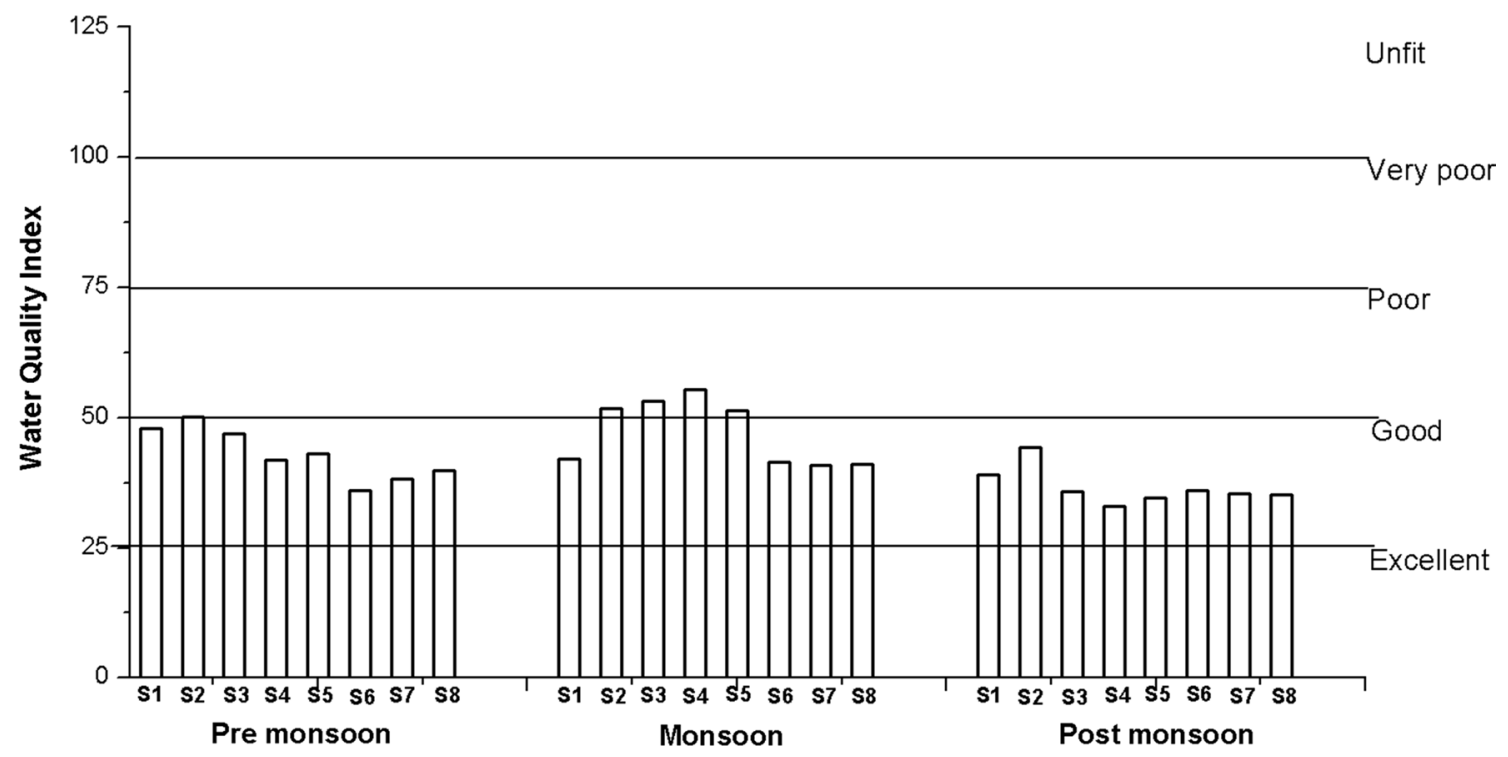

Fig. 4 WQI value of various sampling stations showing a varied pattern of change across seasons

\section{Conclusion}

The study provides us with valuable information about the overall water quality status of the Doyang River by calculating the WQI values. As per the observation, recorded WQI values fall in good water quality status during preand post-monsoon in all the sampling stations and poor water quality status during monsoon in some of the sampling stations that are located upstream of the river. No considerable changes in WQI were observed throughout the study period except in few sites, where a modest increase in WQI was observed during monsoon. The overall average WQI, however, indicated good water quality status. All the physicochemical parameters of water analyzed were within the permissible limit of drinking water quality, and at present, they do not pose a serious threat for different human usage. In the present study, $\mathrm{pH}$, DO and BOD played a significant role in affecting the WQI of the river. Though in the case of nutrient parameters, no such significant roles were observed. Nevertheless, there are disturbances like Jhum cultivation, extensive teak plantation (monoculture) and increased settlements in the catchment area. Annual burning of the forest for shifting cultivation, logging of trees, eco-tourism, poisoning of rivers and use of explosives for fishing can impose a serious threat to the water quality. These activities, if not controlled, could lead to further deterioration of water quality in the near future. To further improve the water quality, proper management policy must be adopted on disposal of sewage by the communities residing in the catchment areas, agricultural runoff, unmanaged landuse practices and unprotected riparian areas. Special focus on community participation in conservation efforts could be helpful. Remedial measures along the riparian zones could play a positive role in future monitoring and improvement of Doyang River water quality.

Acknowledgements This work is financially supported by the major research project (MRP) Grant of the University Grant Commission, New Delhi, India, under sanction order F.No. 43-317/2014 (SR) dated November 17, 2015.

Open Access This article is licensed under a Creative Commons Attribution 4.0 International License, which permits use, sharing, adaptation, distribution and reproduction in any medium or format, as long as you give appropriate credit to the original author(s) and the source, provide a link to the Creative Commons licence, and indicate if changes were made. The images or other third party material in this article are included in the article's Creative Commons licence, unless indicated otherwise in a credit line to the material. If material is not included in the article's Creative Commons licence and your intended use is not permitted by statutory regulation or exceeds the permitted use, you will need to obtain permission directly from the copyright holder. To view a copy of this licence, visit http://creativecommons.org/licenses/by/4.0/.

\section{References}

Akoteyon IS, Omotaya AO, Soladoye O, Olaoye HO (2011) Determination of water quality index and suitability of urban river for municipal water supply in Lagos-Nigeria. Eur J Sci Res 54(2):263-271

APHA (2005) American Public Health Association, Standard Methods for the Examination of Water and Wastewater, Method 1020

Atulegwu PU, Njoku JD (2004) The impact of biocides on the water quality. Int Res J Eng Sci Technol 1:47-52 
Bora M, Goswami DC (2017) Water quality assessment in terms of water quality index (WQI): Case study of the Kolong River. Appl Water Sci, Assam. https://doi.org/10.1007/s13201-016-0451-y

Bouslah S, Djemili L, Houichi L (2017) Water quality index assessment of Koudiat Medouar Reservoir, northeast Algeria using weighted arithmetic index method. J Water Land Dev. https://doi. org/10.1515/jwld-2017-0087

Brown RM, McClelIand NI, Deininger RA, Tozer RG (1970) A water quality index-Do we dare? Water Sew Works 117:339-343

Brown RM, McClelIand NI, Deininger RA, O'Connor MF (1972) A water quality index - crashing the physiological barrier. Indic Environ Qual 1:173-182

Bureau of Indian Standards, BIS 10500 (2003) Manak Bhavan, New Delhi, India

Burt TP, Pinay G (2005) Linking hydrology and biogeochemistry in complex landscapes. Prog Phys Geogr 29(3):297-316

Chatterje C, Raziuddin M (2002) Determination of water quality index (WQI) of a degraded river in Asansol industrial area (West Bengal). In: Kumar A (ed) Ecology of polluted water. APH Pub. Crop., New Delhi, pp 885-895

Debels P, Figueroa R, Urrutia R, Barra R, Niell X (2005) Evaluation of water quality in the Chillan River (Central Chile) using physicochemical parameters and a modified water quality index. Environ Monit Assess. https://doi.org/10.1007/s1066 1-005-8064-1

Devi WS, Singh KR, Meitei NS (2015) Assessment of water quality index of Nambol River, Manipur, India. Uni J Environ Res Technol 5(3):165-172

Ewaid SH (2017) Water quality evaluation of Al-Gharraf river by two water quality indices. Appl Water Sci. https://doi.org/10.1007/ s13201-016-0523-z

Fausch KD, Baxter CV, Murakami M (2010) Multiple stressors in north temperate streams: lessons from linked forest- stream ecosystems in northern Japan. Freshw Biol 55:120-134

Hill AR (1996) Nitrate removal in stream riparian zones. J Environ Qual 25:743-755

Horton RK (1965) An index number system for rating water quality. J Water Pollut Control Fed 37(3):300-306

I.C.M.R (1975) Manuals of standards of quality for drinking water supplies. I.C.M.R, New Delhi

Ikomi RB, Emuh CT (2000) The status of the physicochemical hydrology of Upper Warri River Nigeria. J Sci Environ 2:75-86

Imnatoshi, Ahmed SU (2012) Geomorphology and seasonal variation of Physico-chemical parameters of Doyang River, Nagaland. The Ecoscan 6(1\&2):05-09

Kumar RN, Solanki R, Kumar JIN (2011) An assessment of seasonal variation and water quality index of Sabarmati River and Kharicut canal at Ahmedabad, Gujarat. EJEAFChe 10(5):2248-2261

Laishram S, Yumnam J (2016) State of India's Rivers. https://india riversblog.files.wordpress.com/2017/03/north-east-report.pdf. Accessed 24 Sept 2018

Lowrance R (1998) Riparian forest ecosystem as filters for non-point source pollution. In: Pace ML, Groffman P (eds) Successes, limitations, and frontiers in ecosystem science. Springer, New York
Luke SH, Luckai NJ, Burke JM, Prepas EE (2007) Riparian areas in the Canadian boreal forest and linkages with water quality in streams. Environ Rev 15:79-97

Mayer PM, Reynolds SK, McMutchen MD, Canfield TJ (2007) Metaanalysis nitrogen removal in riparian buffers. J Environ Qual 36:1172-1180

Naubi I, Zardari NH, Shirazi SM, Ibrahim NFB, Baloo L (2016) Effectiveness of water quality index for monitoring Malaysian river water quality. Pol J Environ Stud 25(1):231-239

Othman F, Eldin MEA, Mohamed I (2012) Trend analysis of a tropical urban river water quality in Malaysia. J Environ Monit Assess. https://doi.org/10.1039/c2em30676j

Patel SG, Singh DD, Harshey DK (1983) Pamitae (Jabalpur) sewage polluted water body, as evidenced by chemical and biological indicators of pollution. J Environ Biol 4:437-449

Pradeep JK (1998) Hydrogeology and quality of ground water around Hirapur, District Sagar (MP). Poll Res 17(1):91-94

Prasad B, Bose JM (2001) Evaluation of the heavy metal pollution index for surface and spring water near a limestone mining area of the lower Himalayas. Environ Geol 41:183-188

Semiromi FB, Hassani AH, Torabian A, Karbassi AR, Lotfi FH (2011) Water quality index development using fuzzy logic: a case study of the Karoon river of Iran. Afr J Biotech 10(50):10125-10133

Shah KA, Joshi GS (2017) Evaluation of water quality index for River Sabarmati. Appl Water Sci, Gujarat. https://doi.org/10.1007/s1320 1-015-0318-7

Sharma D, Kansal A (2011) Water quality analysis of River Yamuna using water quality index in the national capital territory. Appl Water Sci, India. https://doi.org/10.1007/s13201-011-0011-4

Singh G, Kamal RK (2014) Application of water quality index for assessment of surface water quality status in Goa. Curr World Environ 9(3):994-1000. https://doi.org/10.12944/CWE.9.3.54

Singh RKB, Singh TC, Singh TR (2016) Assessment of Water quality index of Nambul River, Imphal, Manipur, India. IRJET 3(12):1462-1467

Thakre G, Shrivastava N, Mishra DD, Bijpai A (2010) Limnological studies to assess the water quality of Tapti pond at Multai District, Betul (MP). Int J Che Sci 8(4):2105-2114

Trivedy RK, Goel PK (1986) Chemical and biological methods for water pollution studies. Environmental Publication, Karad

World Health Organization (WHO) (1998) Guidelines for drinking water quality, 2nd edn. Geneva. ISBN 9241545143:36

Yisa J, Jimoh T (2010) Analytical studies on water quality index of River Landzu. Am J Appl Sci 7(4):453-458

Yogendra K, Puttaiah ET (2008) Determination of water quality index and suitability of an urban waterbody in Shimoga town, Karnataka. In: Sengupta M, Dalwani R (eds) Proceeding of taal 2007: the 12th world lake conference, pp 342-346

Publisher's Note Springer Nature remains neutral with regard to jurisdictional claims in published maps and institutional affiliations. 